\title{
APLIKASI HIJAB SHAHABIYAT DI MASA TURUN PERINTAH MENUTUP AURAT (STUDI PEMAHAMAN SOSIO-HISTORIS HADIS PERILAKU WANITA MASA NABI)
}

\author{
Muhamad Arpah Nurhayat \\ UIN Raden Fatah Palembang, arpah.nurbayat@gmail.com \\ Anggi Wahyu Ari \\ UIN Raden Fatah Palembang, anggi.wahyuari26@gmail.com
}

\begin{abstract}
In the aspect of Islamic shari'a, it stipulates matters of daily application, including the manner of dress which is permissible in the Koran. Women get more attention in this matter, considering that their bodies contain beauty that must be covered so that it does not become a spectacle and slander for the opposite sex which is not their mubrim, it is then called aurat. The opinion of the majority of the Ulama is that male genitalia is from the navel to the knees while the female genitalia is the entire body except the face and palms. This article discusses how the application of the bijab in the days of the decree to close the aurat. hijab in the sense of closing the aurat is the command of Allah through his apostle but the boundary of the hijab is not agreed upon by the ulama. In the early days of sahabiyyat, covering their faces and heads, the implementation of the hijab by covering the entire body, including the head and face, was a response to the obedience of sabaiyyat against the command to use the hijab, not a shari'ah order from the Prophet. over time the trend of bijab appears to be inseparable from each other's understanding of the boundaries of women's genitals so that the veil, niqab, and khimar appear, all of which refer to the order to cover the genitals and are greatly affected by the boundaries of the aurat's understanding and fatwa of the ulema.
\end{abstract}

Keywords: Hijab, Shahabiyat, Hadis, Sosio-Historis

\begin{abstract}
Abstrak
Dalam aspek syariah Islam menetapkan hal-hal yang bersifat aplikasi keseharian termasuk cara berpakaian yang dibolehkan dalam Alquran. Perempuan mendapatkan mendapatkan perhatian lebih dalam hal ini, mengingat tububnya mengandung keindahan yang harus ditutupi agar tidak menjadi tontonan dan fitnah bagi lawan jenis yang bukan mubrimnya, hal itu kemudian dinamakan aurat. Pendapat mayoritas Ulama bahwa aurat laki-laki ialah dari pusar hingga lutut sedangkan aurat perempuan adalah seluruh tububnya kecuali wajah dan telapak tangan. Artikel ini membahas tentang bagaimana aplikasi hijab pada masa turunnya perintah untuk menutup aurat. berbijab dalam arti menutup aurat adalah perintah Allab melalui rasulnya namun batasan berbijab tidaklah disepakati oleh ulama. Di masa awal sababiyyat menutup wajah dan kepala mereka pelaksanaan berbijab dengan cara menutupi selurub tubub termasuk kepala dengan wajah adalah respon kepatuhan sahaiyyat terhadap perintah menggunakan hijab bukan perintah yang sharih dari rasulullah Saw. seiring waktu muncul trend berbijab dengan tidak terlepas dari pemahaman masing-masing mengenai batasan aurat perempuan sehingga muncul jilbab, niqab, dan khimar yang kesemuanya mengacu pada perintah menutupi aurat dan sangat terpengaruh oleh batasan aurat dalam pemahaman masing-masing mazhab dan fatwa ulama yang dianutnya.
\end{abstract}

Kata Kunci : Hijab, Shahabiyat, Hadis, Sosio-Historis 


\section{PENDAHULUAN}

Ajaran Islam mengandung beberapa aspek penting meliputi aqidah, syariah dan muamalah yang dalam pelaksanaannya tidak ada yang diabaikan. Alquran dan sunnah Nabi Saw., memberikan arahan dan petunjuk terkait ketiga hal diatas.

Dalam aspek syariah Islam menetapkan hal-hal yang bersifat aplikasi keseharian termasuk cara berpakaian yang dibolehkan dalam Alquran. Perempuan mendapatkan mendapatkan perhatian lebih dalam hal ini, mengingat tubuhnya mengandung keindahan yang harus ditutupi agar tidak menjadi tontonan dan fitnah bagi lawan jenis yang bukan muhrimnya, hal itu kemudian dinamakan aurat.

Sebagai salah satu alat untuk menutup aurat, pakaian merupakan identitas manusia, ia membedakan antara satu individu dengan individu lainnya, bahkan antara satu masyarakat dengan masyarakat yang lain. Salah satu fungsi pakaian adalah untuk menutup aurat, Islam memberikan perbedaan yang sangat signifikan antara aurat pria dan wanita. ${ }^{1}$ Pendapat mayoritas Ulama bahwa aurat laki-laki ialah dari pusar hingga lutut sedangkan aurat perempuan adalah seluruh tubuhnya kecuali wajah dan telapak tangan. ${ }^{2}$ Dari penjelasan di atas, penulis melihat pentingnya meneliti tentang bagaimaan aplikasi hijab pada masa turunnya perintah untuk menutup aurat

\section{AURAT DAN JILBAB MENURUT PARA PAKAR}

Perspketif Ulama.

Jilbab adalah pakaian wanita Muslim, dalam Islam, berhijab diwajibkan bagi wanita untuk menjaga fitrah mereka, dalam Islam wanita memiliki kedudukan yang terhormat, dan diantara penghormatan Islam terhadap wanita

${ }^{1}$ M. Quraish Shihab, Jilbab pakaian wanita Muslimah (Jakarta, Lentera Hati, 2014) h. 34

${ }^{2}$ Felix Y Siaw, Yuk Berbijab! Hijab tanpa nanti, Taat tampa Tapi (Bandung: Mizan, 2013) h. 53 adalah disyari'atkannya jilbab bagi para muslimah, dengan demikian para wanita muslimah tidak menjadi bahan tontonan lakilaki yang bukan mahramnya. Tentang hukum memakai jilbab sendiri telah menjadi perdebatan diantara pakar, ada yang pro dan kontra mengenai batas aurat yang harus ditutup. Menurut Nashiruddin al-Albani ada delapan syarat jilbab bagi wanita Muslimah: 1) Menutup seluruh badan kecuali yang diperbolehkan. 2) Bukan berfungsi sebagai perhiasan. 3) kainnya harus tebal. 4) harus longgar, tidak ketat sehingga menggambarkan sesuatu dari bentuk tubuhnya. 5) Tidak diberi wewangian atau parfum. 6) Tidak menyerupai pakain laki-laki. 7) Tidak menyerupai pakaian wanita non Muslim. 8) bukanlibas Syubrah (pakaian popularitas).

Pendapat lainnya adalah menurut konsep fiqh, K.H Ali Yafie dalam buku Menggagas Fiqih Sosial menyatakan bahwa dalam penalaran fiqih dalam soal pakaian, menitik beratkan pada fungsinya dalam etika pergaulan keluarga dan masyarakat ramai, dan inilah yang merupakan soal pokoknya.Bahannya, bentuknya dan modelnya merupakan wasilah atau sarana untuk mewujudkan fungsi itu. Oleh karena itu, busana perempuan yang beriman tidakterikat pada bentuk atau mode, bahan dan warna dari jilbab di zaman awal, tetapi dapat berkembang dalam batas-batas fungsi, etika dan estetika yang dibenarkan oleh hukum Islam, yang memungkinkan ia berubah dari zaman ke zaman. $^{3}$

Hampir seluruh Ulama salaf berpendapat bahwa wanita harus menutup seluruh tubuhnya kecuali wajah dan telapak tangan, Husein Shahab berpendapat bahwa jilbab adalah suatu hukum yang pasti dan tegas yang mana seluruh wanita muslimah diwajibkan untuk mengenakannya. Melanggar atau tidak 
mematuhinya berarti telah mengingkari salah satu hukum Islam yang esensial. ${ }^{4} \mathrm{Hal}$ yang sama juga diungkapkan oleh Bakar bin 'Abdullah Abu Zaid, bahkan tokoh yang kedua ini lebih ekstrim dalam memandang jilbab, ia mengatakan bahwa wanita wajib menutup wajah dan kedua telapak tangannya apabila berada di luar rumah atau bertemu dengan laki-laki yang bukan muhrimnya. ${ }^{5}$

Al-Maraghiy memaknai jilbab sebagai baju kurung yang meliputi seluruh tubuh perempuan, lebih dari sekedar baju biasa dan kerudung. Mengutip Ibn Mandzur dalam Lisan al Arab, pengertian jilbab yang lazim adalah berupa selendang atau pakaian lebar yang dipakai kaum wanita untuk menutupi kepala, punggung, dan dada. Sedangkan Imam Raghib dalam Al-Mufradat Fii Gharib mengartikan jilbab sebagai pakaian longgar yang terdiri dari baju panjang dankerudung yang menutupi badan, kecuali wajah dan telapak tangan. ${ }^{6}$ Bila beberapa tokoh agama diatas lebih memandang jilbab dari segi besarnya pakaian yang harus dikenakan, maka Muhandy Ibn Haj lebih memberikan gambaran mengenai persyaratan yang harus dipenuhi sehingga jilbab sah untuk dipakai. Beberapa syarat tersebut yaitu :

1. Busana (jilbab) yang menutupi seluruh tubuhnya selain yang dikecualikan. Bagian yang dikecualikan ini meliputi muka dan telapak tangan sesuai dengan ketentuan beberapa hadis dari Nabi Muhammad SAW.

2. Busana yang bukan untuk perhiasan kecantikan atau tidak berbentuk pakaian aneh, menarik perhatian, dan tidak berparfum (wangi-wangian).

${ }^{4}$ Husein shahab, Jilbab Menurut Alquran dan asSunnah (Bandung: Mizan, 2005), h 8.

5 Bakar bin 'Abdullah Abu Zaid, Menjaga Kehormatan terj. Gunaim Ihsan (Jakarta: AsShofwa, 2003), h 30-33.

6 Muhammad Shahrur, al-Kitab wa al-Qur'an: Qira'ah Mu'ashirah, h 247.
3. Tidak tipis sehingga tampak bentuk tubuhnya.

4. Tidak sempit sehingga tampak bentuk tubuhnya.

5. Busana yang tidak menampakan betisnya (kaki) atau celana panjangyang membentuk kakinya dan kedua telapak kakinya pun harus tertutup.

6. Tidak menampakan rambutnya walau sedikit dan tidak pula lehernya

7. Busana tidak menyerupai pakaian laki-laki dan tidak menyerupai pakaian wanita-wanita kafir yang tidak islami. ${ }^{7}$

Perbedaan pandangan para ulama soal busana perempuan ini sangat dipengaruhi oleh perbedaan pandangan tentang batas-batas aurat yang harus ditutupi perempuan. Untuk mengkaji permasalahan tersebut, kita mulai dengan menelusuri arti kata jilbab itu sendiri. Kata jilbab berasal dari kata kerja "jalaba" dalam bahasa Arab yang bermakna "menutup sesuatu dengan sesuatu yang lain sehingga tidak dapat dilihat". Dari pengertian tersebut, secara spesifik masih banyak ulama yang berbeda pendapat tentang pengertian jilbab. Sebagian pendapat mengatakan jilbab itu mirip Rida' (sorban), sebagian lagi mendefinisikannya dengan kerudung yang lebih besar dari Kbimar. Khimar adalah istilah umum untuk pakaian penutup kepala dan leher. Sebagian lagi mengartikannya dengan Qina yaitu penutup muka atau kerudung lebar. ${ }^{8}$

Dari berbagai pengertian diatas, dapat dipahami bahwa ulama sepakat akan wajibnya menutup aurat bagi laki-laki dan perempuan, namun mereka berbeda pendapat tentang batas aurat tersebut, salah satu cara menutup aurat adalah dengan memakai jilbab.

\footnotetext{
${ }^{7}$ Kusumayadi.; Amir Taufik, Enam Puluh Satu Tanya Jawab Mengenai Jilbab (Kuala Lumpur: Pustaka Jasmin, 1989), h 18.

${ }^{8}$ Kusumayadi.; Amir Taufik, Enam Pulub Satu Tanya Jawab Mengenai Jilbab, h 26.
} 


\section{Menurut Cendikiawan.}

Dalam Islam Jilbab merupakan pakaian perempuan, apabila kita merujuk kepada ensiklopedi hukum Islam, pakaian adalah sesuatu atau barang yang dipakai oleh manusia di badan. Pakaian merupakan sesuatu yang harus bagi laki-laki dan perempuan, sebab ia merupakan pelindung yang dibutuhkan oleh kesehatan, ia juga merupakan penutup yang melindungi sesuatu yang menyebabkan malu apabila terlihat oleh orang lain dan ia merupakan perhiasan yang disukai oleh fitrah tanpa beban. ${ }^{9}$ Jilbab dalam ensiklopedi ini diartikan sebagai baju kurung lapang yang dapat menutup kepala, muka, dan dada.

Menurut Fadwa El Guindi, jilbab jika diistilahkan dalam bahasa Inggris bukan hanya sekedar seperti scarf (semacam selendang atau syal), melainkan dapat diistilahkan dengan veil (atau voile dalam bahasa Perancis) yang biasa dipakai untuk merujuk pada penutup kepala tradisional, wajah atau tubuh wanita di Timur Tengah dan Asia Selatan ${ }^{10}$. Sedangkan di Indonesia, jilbab kerap disamakan pengertiannya dengan hijab, yang dimaknai sebagai pakaian longgar, atau kerudung (simple handscarf). Bahkan bagi El Guindi, jilbab di Indonesia dapat merujuk pada corak pakaian Islam namun seringkali maknanya tidak konsisten. Dalam hal ini jilbab bukan hanya sebagai penutup kepala saja, melainkan menjadi kesatuan dengan pakaian yang digunakan seorang perempuan muslim.

Namun jika dilihat dalam konteks sejarah perkembangan agama, konsep hijab atau jilbab sebenarnya bukan hanya milik Islam, karena dalam beberapa kitab sebelumnya (kitab Taurat), ataupun kitab suci agama Yahudi, juga dikenal beberapa istilah yang semakna dengan hijab yaitu tif'eret. Demikian pula dalam kitab Injil, ditemukan

\footnotetext{
9 Abdul Aziz Dahlan, Ensiklopedi Hukum Islam (Jakarta: Ichtiar Baru, 1993), h. 167.

10 Fadwa El Guindi, Jilbab; Antara Kesalehan, Kesopanan dan Perlawanan (Jakarta: Serambi, 2008), h.
}

istilah semakna, dengan sebutan zammah, re'alah, zaif, dan mitpahat ${ }^{11}$. Bahkan menurut Nasarudin Umar (Universitas Islam Negeri, Jakarta), hijab dalam arti penutup kepala sudah dikenal sebelum adanya agama-agama Samawi (Yahudi dan Nasrani).Tradisi penggunaan kerudung juga telah dikenal dalam hukum kekeluargaan Asyiria.Dengan demikian, jilbab ataupun hijab memiliki istilah yang sebenarnya bukan hanya merupakan masalah sederhana, karena jilbab memiliki pengertian antara pakaian wanita (aspek tubuh) dan lintas budaya.Dalam hal ini, meski secara mendasar jilbab dapat diartikan sebagai kain yang digunakan untuk menutup kepala perempuan, namun dalam konteks kemasyarakatan, jilbab juga menyuguhkan pada dua sisi yang dapat menjadi berbeda dan saling bertentangan. Di satu sisi terdapat upaya pelarangan, dan di sisi lain ada upaya pemaksaan atau keharusan dalam pemakaiannya.

Muhammad Syahrur seorang tokoh kontroversial dalam kitabnya "Alkitab wa al Qur'an: Qira'ah Mu'asyirab" juga membahas masalah hijab dengan menggunakan metode intertekstualitas dan dengan menggunakan pendekatan linguistik sintagmatis. Hasilnya, Syahrur mendapatkan pandangan yang berbeda dengan kebanyakan ulama dalam masalah hijab. Bagi Syahrur, kata al-kbumur dalam Surat al-Nur: 31 tidak bermakna 'tutup kepala' seperti yang lazim diketahui, namun yang di maksud adalah segala macam penutup tubuh baik kepala maupun anggota badan yang lain. Dikaitkan dengan konsep Syahrur tentang al-hadd al-adna (batasan minimal) dan al-hadd ala'la (batas maksimal), yang kemudian dibandingkan dengan hadis Nabi saw yangmenyatakan bahwa seluruh bagian tubuh wanita adalah aurat, maka dapatdisimpulkan bahwa bagian tubuh yang termasuk kategori aljuyub (lekuk tubuhyang mempunyai celah dan bertingkat; seperti bagian di antara kedua buah

11 Nong Darol Mahmadah, Kritik Atas Jilbab menurut Muhammad Said Al-Asymawi,h. 20. 
dada,di bawah buah dada, di bawah ketiak, kemaluan, dan kedua bidang pantat) adalahalbadd al-adna. Adapun bagian tubuh seperti wajah, telapak tangan, dan telapak kaki adalah al-hadd al-a'la. Konsekuensinya, seorang wanita yang menutup seluruh anggota tubuhnya berarti ia telah melanggar budud Allah, begitu jugawanita yang memperlihatkan tubuhnya lebih dari anggota yang termasuk kategori aljuyub. ${ }^{12}$

Menurut Said Ramadhan al-Buti, Islam mewajibkan kepada perempuan untuk berhijab karena di dunia ini banyak terjadi interaksi sosial antara kaum laki-laki dan perempuan, interaksi dan kerjasama ini tidak dapat dihindari karena mereka sama-sama bertanggung jawab atas kemajuan dan pembangunan masyarakat dan peradaban. Interaksi tersebut seringkali membawa kepada hal yang negatif apabila potensi-potensi fitnah antara dua manusia yang berbeda jenis ini tidak diberlakukan syarat-syarat yang membuat kedua belah pihak saling menjaga dan menghormati kesucian mereka, salah satu syarat tersebut adalah menutup aurat (dengan memakai jilbab/hijab bagi perempuan). ${ }^{13}$

12 Muhammad Shahrur, al-Kitab wa al-Qur'an: Qira'ah Mu'ashirah (Kairo dan Damaskus: Sina lil alNasr, 1992), h. 245.

13 Ramadhan Al-Buti menceritakan penglamannya menghadiri sebuah pertemuan akademik di Jerman, ketika salah satu perempuan Jerman dipanggil untuk menyampaiakan urainnya, seperti perempuan kebanyakan di Barat ia berpakaian sangat minim, dan setiap gerak-geriknya menjadi sorotan publik, pada saat itu menurut al-Buti hamper semua wajah pria di ruangan tersebut melihat dengan gejolak nafsu kepada perempuan tersebut dan melupakan orasi ilmiahnya yang bagus. Menurutnya ini adalah sebuah penghinaan kepada seorang perempuan dan penghinaan itu sendiri muncul karena perempuan itu sendiri yang tidak menutup hal yang rawan dalam tubuhnya. Menurutnya, seluruh Muslimah apabila berada diposisi perempuan Jerman tersebut pasti tidak akan mempertontonkan apapun kecuali ide-ide cemerlang yang mereka miliki, hal ini karena Islam sebagai agama mengharuskan umatnya untuk menutup aurat. Lihat Muhammad said Ramadhan al-Buthi, Perempuan: Dalam Pandangan Barat dan Islam Terj. Nuruddin (Yogyakarta, Suluh Press, 2005) h. 178-180.
Al-Buthi mengkritik pendapat beberapa pakar yang mengatakan bahwa tujuan menggunakan jilbab adalah untuk mendidik wanita berakhlak dan mejauhkan dirinya dari dekadensi moral, asumsi ini menurutnya dijadikan sebagai himah dari pensyariatan jilbab bagi kaum Muslimah, kemudian ketika mereka menemukan seorang Muslimah berjilbab yang tidak terpuji akhlaknya, mereka mengkritik hikmah ini dan mengatakan bahwa tidak ada korelasi antara pendidikan jiwa yang ditimbulkan dengan cara atau mode berpakaian seseorang, mereka beranggapan bahwa perempuan yang terdidik dan berakhlak mulia tidak akan lari dari akhlaknya walaupun ia menggunakan pakaian yang sopan, sebaliknya perempuan yang tidak baik akhlaknya tidak akan bisa menjadi baik walaupun menggunakan jilbab/hijab. ${ }^{14}$

Pendapat berbeda dikemukakan oleh Muhammad Sa’id al-Asymawi, menurutnya jilbab bukan merupakan sebuah kewajiban, bahkan lanjutnya tradisi berjilbab yang dilakukan oleh para Sahabat dan tabi'in lebih merupakan keharusan budaya dari pada ajaran agama.Karena itu menurut al-Asymawi memakai jilbab tidak memiliki konsekuensi iman-kafir, selama dasarnya tetap kesopanan dan kehormatan. ${ }^{15}$ Senada dengan ini Husein Muhammad mengatakan bahwa pemakain jilbab ditujukan untuk membedakan antara perempuan merdeka dan hamba sahaya, dikarenakan budak/hamba sahaya pada zaman sekarang ini hampir sudah tidak ada maka pemakaian jilbab harusnya tidak diwajibkan lagi karena illat hukumnya tidak ada, namun apabila ada yang ingin memakainya juga tidak dilarang. ${ }^{16}$

14 Muhammad said Ramadhan al-Buthi, Perempuan: Dalam Pandangan Barat dan Islam Terj. Nuruddin, h. 194.

${ }^{15}$ Muhammad Sa'id al-Asymawi, Kritik Atas Jilbab terj. Novriantoni Kahar ( Jakarta: Jaringan Islam Liberal, 2003) h. 15.

16 Husein Muhammad,Islam Agama Ramah Perempuan (Yogyakarta: LKIS, 2003), h. 215. 
Nazira Zein seorang cendikiawan asal Lebanon mencoba melihat jilbab dari perspektif sosial, ia mencoba membandingkan antara jumlah muslimah yang berjilbab dan yang tidak memakai jilbab, ia mengatakan bahwa jumlah muslimah yang berjilbab tidak lebih dari beberapa juta yang tinggal di perkotaan, muslimat yang tinggal di pedesaan di dunia Islam lebih dari 1700 juta tidak berjilbab, mereka menoak jilbab yang sebelumnya mereka pakai. ${ }^{17}$ Lebih lanjut ia menyatakan bahwa Negara yang menolak jilbab adalah Negara-negara yang telah maju dari aspek intelektual dan materil, kemajuan tersebut tidaklah sama dengan Negara-negara yang memberlakukan jilbab kepada para wanitanya. Bangsa-bangsa yang tidak memberlakukan jilbab adalah mereka yang telah mampu menemukan rahasia-rahasia alam melalui hasil riset dan studi serta mampu menmpatkan unsur-unsur fisik di bawah kendali mereka.Di Negara yang muslimatnya memakai jilbab tidak mampu menggali rahasiarahasia tersebut, mereka hanya mampu menyanyikan lagu-lagu tentang keagungan tradisi-tradisi kuno dan masa lalu, dan dengan nyanyian tersebut mereka terlelap di dalam kejumudan. Menurutnya di Barat perilaku orang sangat dipengaruhi dengan pendidikan yang tinggi dan pelajaran moral sehingga pemakaian jilbab atau tidak memakainya tidak mempengaruhi penghormatan laki-laki kepada perempuan.

Dari penjelasan di atas kita bisa mengambil kesimpulan bahwa berbeda dengan para ulama, cendikiawan ada yang menganggap jilbab merupakan ajaran yang harus dipatuhi dan memakainya menyebabkan kaum wanita terlindung dari gangguan dan gunjingan para laki-laki, namun ada juga yang menganggap bahwa jilbab hanya anjuran yang tidak bisa lepas dari ruang dan waktu, saat ayat tentang perintah memakai jilbab turun kita harus

17 Charlez Kurzman, Wacana Islam Liberal (Jakarta: Paramadina, 2003), h. 135-136. melihat kepada persoalan mengapa perintah itu diturunkan, ketika kita dihadapkan kepada zaman dimana kriminalisasi terhadap perempuan sudah tidak ada maka perintah berjilbab tersebut gugur dengan sendirinya. Demikian penjelasan sebagian cendikiawan mengenai aurat dan jilbab.

\section{PERINTAH MENUTUP AURAT}

Secara etimologi kata aurat berasal dari akar kata "aaraa" yang memunculkan turunan kata awira (menjadikan buta) dan awwara (memalingkan) al-awwar (aib) al-aura (perbuatan keji) dan al-aurat yaitu segala yang memunculkan rasa malu.

Secara termonologi aurat diartikan sebagai sesuatu yang terbuka, kemaluan, telanjang, aib dan cacat. aurat dipahami sebagai sesuatu yang harus ditutupi karena merasa malu jika terlihat atau diketahui orang lain.

Perintah untuk menutupi aurat hakikatnya ditujukan untuk laki-laki dan perempuan Allah SWT., berfirman:

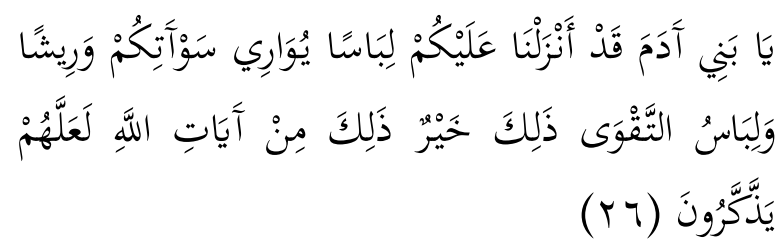

"Hai anak Adam, sesunggubnya Kami telah menurunkan kepadamu pakaian untuk menutup auratmu dan pakaian indah untuk perbiasan. Dan pakaian taqwa itulab yang paling baik. Yang demikian itu adalab sebagian dari tanda-tanda kekuasaan Allah, mudah-mudahan mereka selalu ingat.” (QS. Al-Araf :26)

Seperti yang telah disebutkan sebelumnya bahwa aurat adalah sesuatu yang harus ditutupi, Alquran mengistilahkannya dengan sauaat. Libas (pakaian) adalah penutup aurat sedangkan riyasy dan risy adalah yang secara lahir digunakan untuk keindahan libas adalah yang pokok sedangkan risy adalah penyempurna (Ibnu Katsir 2: 307 )

Pada ayat diatas dijelaskan bahwa ada dua hal yang Allah SWT., telah anugrahkan yaitu pakaian untuk menutup aurat dan risy 
untuk keindahan. Menutup aurat seperti pada ayat diatas ditujukan untuk bani adam (anak cucu adam) secara umum yang artinya laki-laki maupun perempuan menjadi objek perintah diatas.

Allah SWT, memberikan penutup keburukan materi yaitu pakaian dan risy yaitu pakaian yang terbuat dari bulu burung dahulu orang-orang menggunakannya untuk menghiasi pakain dan untuk hal yang bersifat maknawi taqwa adalahan pakainnya (Syarawi, 7 :4095)

Pakaian sudah merupakan salah satu ciri pembeda antara manusia dan makhluk lainnya, dalam setiap peradaban pakaian selalu hadir sebagai pelengkap kehidupan. Begitu juga dengan fungsinya sebagai perhiasan dewasa ini Fassion menjadi sangat menjamur dan diperlombakan, terkadang fungsi keduanya berjalan bersama seperti model hijab yang memiliki dua nilai yaitu penutup aurat dan nilai estetika dengan warna yang beragam, asesoris yeng melekat juga bentuknya yang bermacam-macam.

Selain kedua fungsi yang telah disebutkan, bagi seorang muslimah tradisi menutup aurat menjadi identitas yang melekat pada dirinya dan membedakannya dengan tradisi jahiliyyah dalam Alquran Allah melarang perempuan muslimah bertabarruj layaknya kaum jahiliyyah

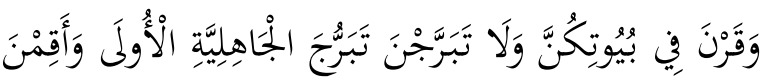

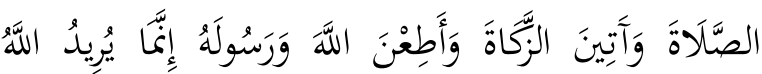

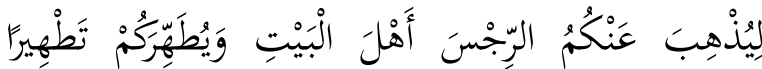

"Dan bendaklab engkau tetap di rumabmu dan janganlah berbias serta bertingkah laku seperti orangorang jahiliyah dulu." (QS. Al-Ahzab: 33)

Ibnu Katsir menukil pendapat beberpa tokoh terkait apa yang dimaksud dengan tabarrij pada ayat ini diantaranya sebagai berikut:
Mujahid berkata: dahulu para perempuan keluar berjalan didepan kaum lakilaki itulah yang dimaksud tabarruj. Muqatil berkata tabarrij adalah menutup kepala namun tidak diikatkan maka tampak kalung dan lehernya.

Selain perintah dalam Alquran hadis Nabi Saw., juga menekankan keharusan berhijab untuk menutupi aurat wanita seperti pada hadis berikut ini:

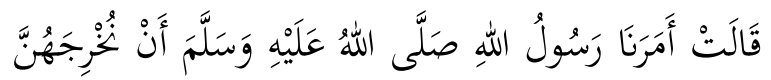

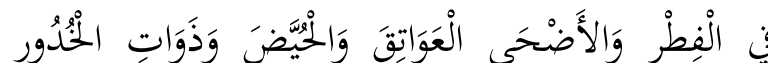

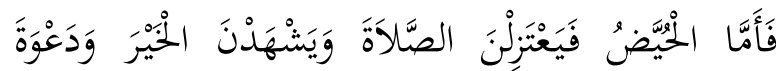

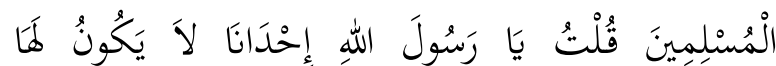

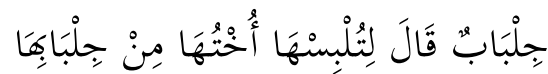

Kami diperintabkan oleh Rasulullah Saw., untuk keluar pada saat Idul Fitri dan Idul Adha, baik para gadis, perempuan yang sedang haid, maupun gadis-gadis pingitan. Wanita yang sedang haid diperintabkan meninggalkan shalat serta menyaksikan kebaikan dan dakwah (syiar) kaum Muslim. Aku bertanya, "Ya Rasulullah, salah seorang diantara kami ada yang tidak memiliki jilbab. Rasulullah Saw. bersabda: Hendaklah saudarinya memakaikan jilbab miliknyanya." (HR Muslim: 2093)

Ayat dan hadis diatas merupakan landasan bagi muslimah untuk menggunakan hijab yang dilaksanakan oleh mayoritas muslimah dari masa kemasa dengan model atau tampilan yang beragam.

Dalam melaksanakan perintah menutup aurat kaum muslimah mengaplikasikannya melalui cara berpakaian yang dinamakan ber jilbab atau berhijab. Jilbab adalah kerudung lebar yang dipakai wanita Muslimah untuk menutup kepala, leher sampai dada. (Kamus Umum Bahasa Indosenia: 490)

Felix Siauw, mendefinisikannya sebagai sesuatu yang ditujukan untuk melindungi perhiasan wanita dan keindahannya, bukan justru menjadi perhiasan baru atau pengganti keindahan itu sendiri, 
sehingga hakikat berjilbab adalah melindungi perhiasan wanita sehingga ia tidak menjadi perhatian laki-laki. (Felix Y Siaw: 107)

Para ulama tafsir tidak sepakat dengan definisi di atas, tetapi mereka sepakat bahwa jilbab merupakan pakaian yang lebar dan longgar untuk menutupi kepala dan dada. (Husein Shahab :60.)

Ada beberapa bentuk hijab yang saat ini berkembang yaitu jilbab, niqab, burka dan amira,biasa disebut juga dengan khimar atau chador yang semuanya mudah ditemukan disekitar kita. Hijab merupakan cara menutup aurat dengan menutupi kepala dan leher tetapi wajah tetap tampak. niqab adalah jilbab yang menutupi kepala, leher dan muka namun tetap memperlihatkan mata. Biasanya penutup mukanya terpisah dengan jilbab yang dikenakan. burka merupakan jilbab yang menutupi kepala, leher dan mata, sehingga tidak ada bagian tubuh yang tampak. pada bagian mata kain lebih tipis yang berguna untuk melihat. Almira menggunakan dua potong jilbab. Terdiri dari penutup kepala yang seperti topi dan syal. Khimar adalah jilbab panjang yang menggantung hanya sebatas pinggang. Biasanya menutupi rambut, leher dan bahu, namun wajah masih terlihat dengan jelas.

Semua jenis yang penulis sebut diatas berfungsi sama yaitu menutup aurat perempuan lazimnya setiap yang berniqab pasti berhijab namun tidak sebaliknya hal ini karena adanya perbedaan pemahaman terkait batasan aurat bagi perempuan dewasa

\section{TUJUAN BERHIJAB}

Tujuan berhijab dimasa awal kedatangan Islam adalah untuk memperkenalkan diri bahwa mereka adalah perempuan baik-baik agar mereka tidak diganggu oleh orang lain dalam surah AlAhzab diterangkan sebagai berikut:

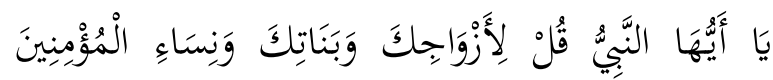

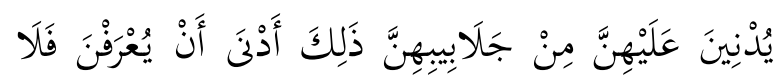

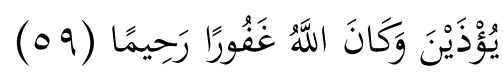

"Wahai Nabi, katakanlah kepada istri-istri, anakanak perempuan dan istri-istri orang Mukmin, Hendaklab mereka mengulurkan jilbabnya ke selurub tubub mereka.' Yang demikian itu supaya mereka mudah dikenali, oleh sebab itu mereka tidak. diganggu. Dan Allab adalah Maha pengampun lagi Maha Penyayang."

Ayat diatas memerintahakan kepada setiap mukminat melalui lisan nabi Saw untuk mengulurkan jilbab mereka keseluruh tubuh. Dengan tujuan agar mereka mudah dikenal sebagai identitas perempuan yang baik, merdeka dan menjauhkan mereka dari gangguan, disisi lain mereka juga diperintahkan untuk menjaga pandangan mereka dan berusaha untuk tidak memancing kemungkinan datangnya keburukan dari orang lain dengan melarang memperlihatkan perhiasan (kecantikannya) kepada orang yang tidak boleh melihatnya

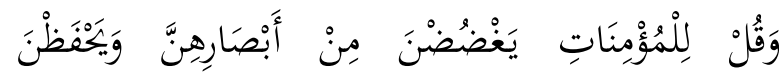

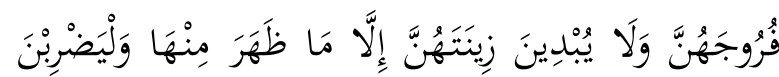

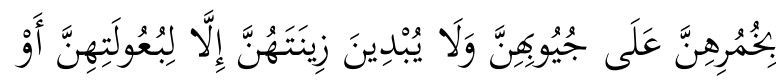

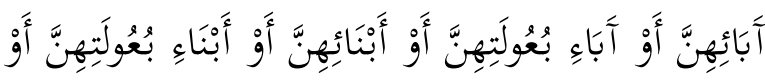

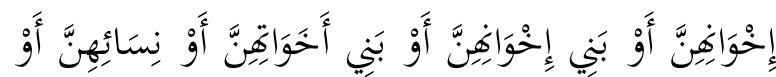

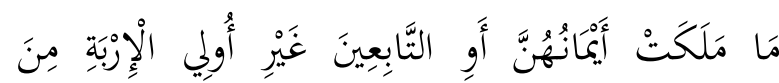

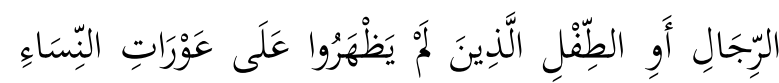

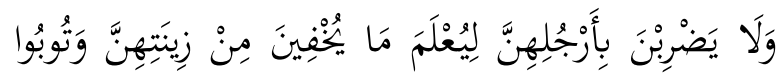

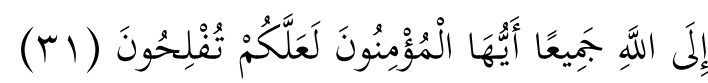
"Hendaklah mereka menahan pandangannya, dan kemaluannya, dan janganlah mereka menampakkan perbiasannya, kecuali yang (biasa) nampak dari padanya. Dan hendaklab mereka menutupkan kain kudung ke dadanya, dan janganlab menampakkan perbiasannya kecuali kepada suami mereka, atau ayah mereka, atau ayah suami mereka, atau puteraputera mereka, atan putera-putera suami mereka, atan 
Sandara-sandara laki-laki mereka, atau puteraputera saudara lelaki mereka, atan putera-putera saudara perempuan mereka, atau wanita-wanita islam, atau budak-budak yang mereka miliki, atau pelayan-pelayan laki-laki yang tidak mempunyai keinginan (terbadap wanita) atau anak-anak yang belum mengerti tentang aurat wanita. Dan janganlah mereka memukulkan kakinya agar diketahui perbiasan yang mereka sembunyikan. Dan bertaubatlah kamu sekalian kepada Allah, Hai orang-orang yang beriman supaya kamu beruntung." (QS. An-Nur :31)

\section{MUKALLAFAH BERHIJAB}

Bila tujuan berhijab adalah untuk menjaga diri dari munculnya gangguan orangorang yang usil tentu objek yang menjadi maballu at-taklif adalah yang masuk dalam katagori tertentu batasan tersebut dapat dilihat dari riwayat berikut ini:

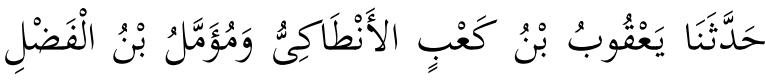

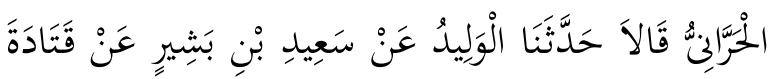

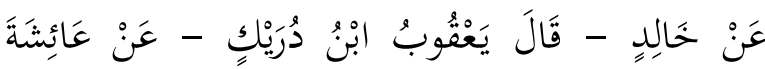

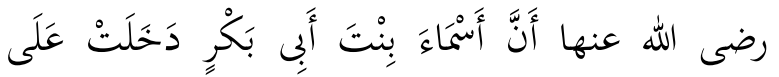

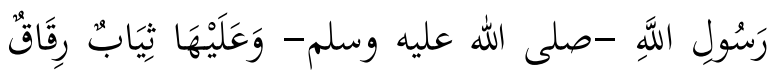
فَأَعْرَضَ عَنْهَا رَسُولُ اللَّهِ -صلى الله عليه وسلم - وَقَّاَل

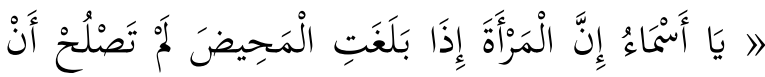

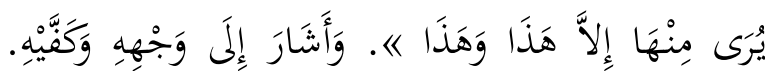

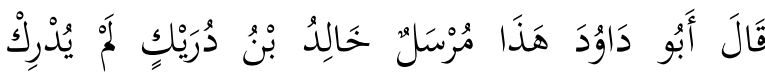

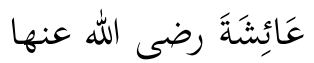

Dari Aisyah ra babwa Asma binti Abu Bakar masuk menemui Rasulullah Saw., sedang ia memakai pakaian tipis maka rasululaah Saw., bersabda kepadanya Wahai Asma sesunggubnya seorang wanita, apabila telah balig (mengalami haid), tidak layak tampake dari tububnya kecuali ini dan ini (seraya menunjuk muka dan telapak tangannya). (HR. Abu Dawud: 410)

Sementara batas ketentuan ini berlaku pada perempuan adalah masa tua yang laki-laki tidak lagi tertarik untuk menikahinya

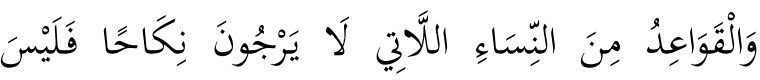

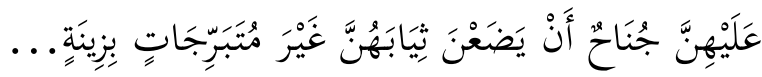
"Dan perempuan-perempuan tua yang telah terbenti (dari haid dan mengandung) yang tiada ingin kawin (lagi), tiadalah atas mereka dosa menanggalkan pakaian mereka dengan tidak (bermaksud) menampakkan perbiasan...” (QS. An-Nur: 60.)

Ayat diatas menjelaskan bahwa perempuan-perempuan yang sudah tua, tidak lagi menimbulkan hasrat bagi laki-laki untuk menikahinya maka dibolehkan untuk menanggalkan pakaian mereka tanpa bermaksud untuk tabarruj. Dari sini dapat fahami tujuan berhijab adalah sebagai pelindung bagi perempuan. Dengan kata lain yang masuk dalam taklif adalah perempuan yang masih menarik, menawan lawan jenisnya atau dapat membangkitkan syahwat sementara anak perempuan yang masih kecil dan perempuan yang sudah renta tidak masuk kedalamnya karena tidak adanya kemungkinan untuk membangkitkan syahwat dari lawan jenisnya.

\section{BATASAN AURAT PEREMPUAN}

Para ulama dari masa kemasa sepakat akan wajibnya menutup aurat namun terjadi perbedaan dalam menentukan batasannya yang dapat penulis simpulkan pada poin berikut aurat bagi perempuan dewasa adalah:

Pertama seluruh anggota badan sehingga yang boleh tanpak hanyalah pakaiannya seperti pendapat Ibnu Mas'ud (AlKhazin, 1399 H:235). Senada dengan pendapat ini banyak ulama setelahnya berpendapat bahwa wanita itu aurat

$$
\begin{aligned}
& \text { أإن المرأة عورة ومأمورة بالإجتجاب والستر ومنهية عن التبرج } \\
& \text { وإظهار زيتنها ومحاسنها }
\end{aligned}
$$

Sesungoubnya wanita itu aurat dan diperintah untuk. menutupinya dan dilarang untuk bertabarrij dan menampakan perbiasan dan keindahannya. (Muhammad Abdul Maqshur Afifi 2002: 439) 
Sebuah hadis yang diriwayatkan oleh Abdullah menjadi landasan pendapat ini:

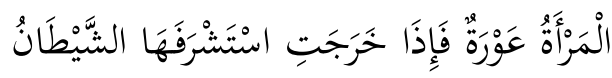

Sesunggubnya wanita itu aurat dan jika ketika keluar (rumah) mereka dielukan oleh Syaithan (Tirmidzi: 1206)

Kedua seluruh badan kecuali wajah dan kedua telapak tangan. Khazin menafsirkan ayat wala yubdina zinatabunna dengan segala yang tersembunyi yang tidak boleh ditampakkan saat shalat dan kepada laki-laki yang bukan muhrim yaitu selain wajah dan telapak tangan. (Al-Khazin, 1399 H:235).

Ketiga seluruh badan kecuali wajah dan kedua telapak tangan dan pakaian yang dikenakannya Al-Qurthubi menukil pendapat beberapa tokoh dibawah ini:

قال سعيد بن جبير أيضا وعطاء والاوزاعي: الوجه والكفان والثياب. وقال ابن عباس وقتادة والمسور بن مخرمة: ظاهر الزينة هو الكحل والسوار والخضاب إلى

$$
\text { نصف الذراع }
$$

Said bin Jabir, Atha dan Aurai menafsirkan illa maa drahara minha dengan muka dan telapak tangan serta pakaian sementara Ibnu Abbas dan Qatadab dan Musawwar berpendapat babwa yang dzabir maksudnya adalah perbiasan yang tampak yaitu: celak mata, gelang, setengah dari tangan yang dalam tradisi wanita Arab dibiasi dengan inai, anting, cincin dan laimmya sepenti pendapat Qatadah dan Miswar (Al Quntbubi, 1998:335)

Kelima batas aurat wanita tidak ditegaskan dalam Alquran seperti pendapat Quraisy Shihab. Baginya sangat penting untuk menjadikan adat kebiasaan sebagai pertimbangan dalam penetapan hukum, namun dengan catatan adat tersebut tidak lepas kendali dari prinsip-prinsip ajaran agama serta normanorma umum.Karena itu ia sampai kepada pendapat bahwa pakaian adat atau pakaian nasional yang biasa dipakai oleh putri-putri Indonesia yang tidak mengenakan jilbab tidak dapat dikatakan telah melanggar aturan agama (Shihab, 1996:179

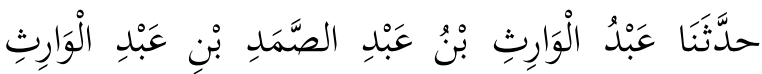

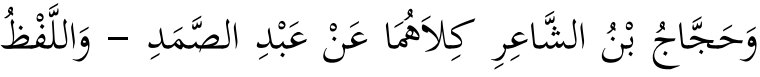

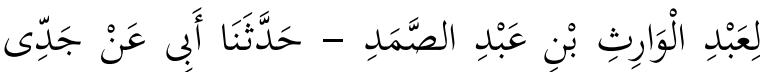

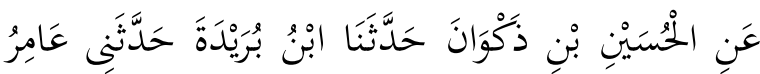

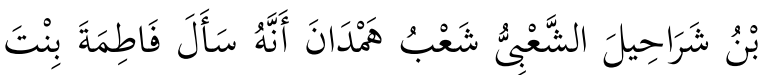

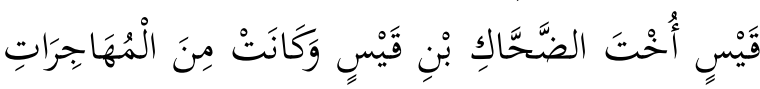

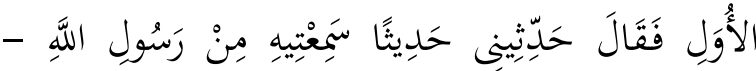

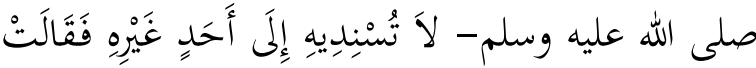

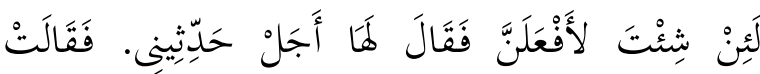

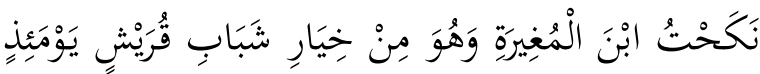

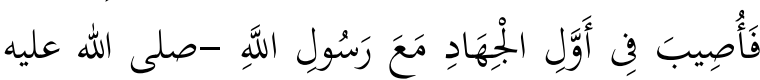

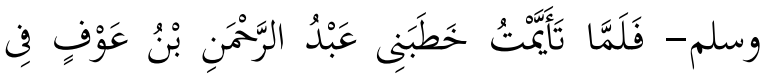
نَفَرِ رِنْ أَصْحَابِ رَسُولِ اللَّهِ -صلى الله عليه وسلم وَخَطَبَنى رَسُولُ اللَّهِ -صلى الله عليه وسلم- عَّلَى مَوْلاهُ

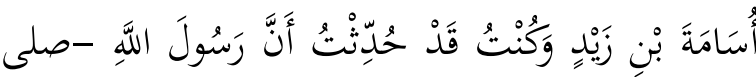

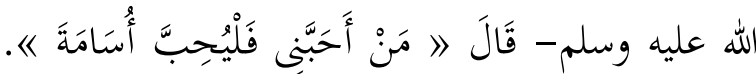

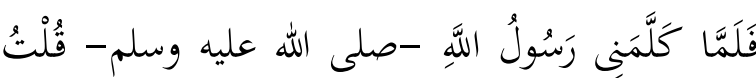

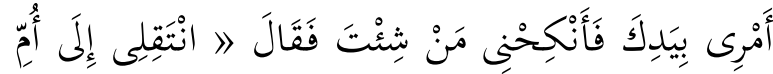

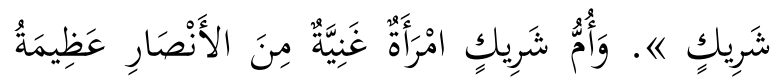

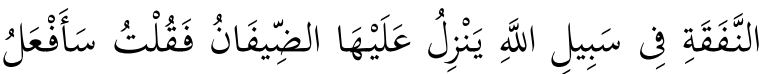

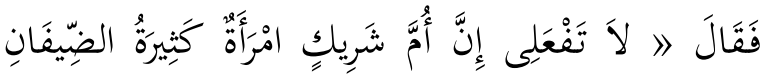

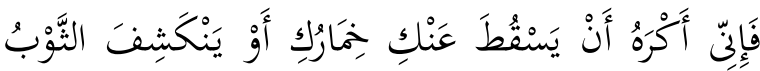

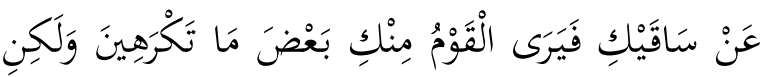

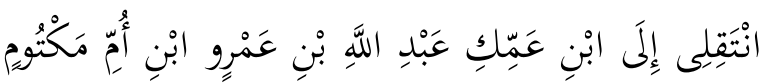

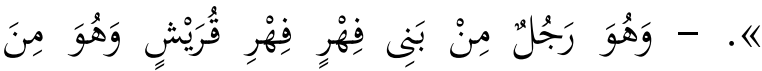

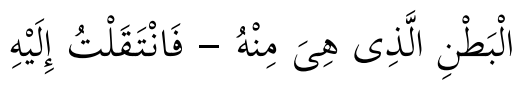

"Jangan (kamu pindab kerumabnya), karena Ummu Syuraik adalah wanita yang banyak tamunya, aku tidak mau kerudungmu jatuh atau penutup betismu 
tersingkap lalu orang-orang melihat sebagian yang tidak kau suka."(HR. Muslim: 2942)

Dari bahasan diatas dapat diperhatikan beberapa poin penting terkait hijab yaitu: Bahwa menutup aurat adalah kewajiban bagi laki-laki dan perempuan, larangan bertabarruj seperti yang dilakukan wanita jahiliyyah, Tujuan berhijab adalah untuk memelihara diri dari fitnah dan gangguan, Wanita yang sudah tua diperkenankan menanggalkan hijabnya.

\section{RESPON DAN PERAKTEK SAHABIYAT TERHADAP PERINTAH BERHIJAB}

Dalam beberapa riwayat digambarkan bahwa para sahabiat diperintahkan menutup wajah mereka sedang dalam riwayat Abu dawud dibolehkan membuka wajah dan telapak tangan.

Berikut ini penulis sajikan hadis-hadis nabi Saw., yang menggambarkan respon sahabiyat terhadap perintah berhijab dalam Alquran yang sengaja penulis angkat dengan tujuan agar dapat membandingkan penerimaan awal dan respon yang muncul dengan kondisi saat ini dikalangan akademisi.

\section{$\underline{\text { Hadis Pertama }}$}

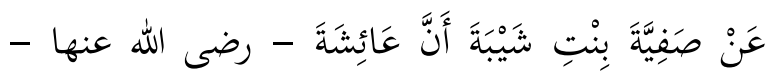

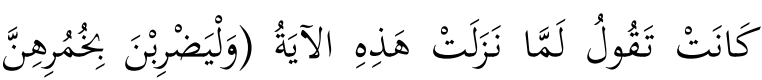

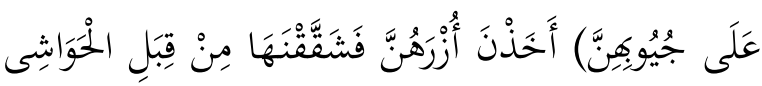
فَاخْتَمَرْنَ بِكَا

Dari Shafiyyah binti Syaibah babwa Aisyah ra.

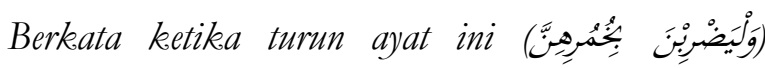
mereka mengambil kain dan mereka menyobeknya dan menutup muka dengannya (Bukhari: 4759)

Dalam riwayat ini tergambar respon cepat para shahabiat dalam melaksanakan perintah menutup wajah mereka dengan kain walaupun harus merobeknya tanpa menunggu lagi. Respon sepontan seperti ini biasa terjadi dimasa Rasulullah Saw. sebagai perbandingan dapat dilihat saat turun perintah menghadap qiblat dalam kondisi shalat menghadap Baitul Maqdis sepontan kaum muslimin mengalihkan badan mereka kearah kabah.

\section{$\underline{\text { Hadis Kedua }}$}

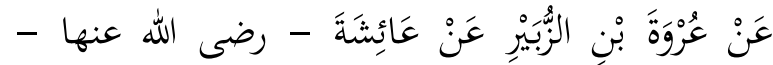

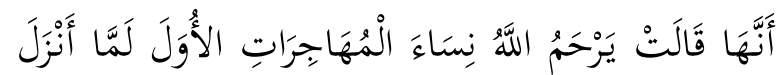

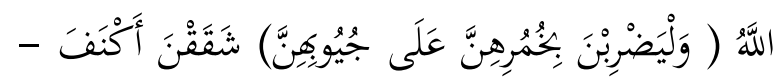

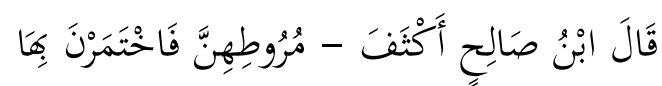
Dari Urwab bin Zubair dari Aisyah ra. babwa Ia berkata semoga Allah merahmati perempuanperempuan Anshar saat Allah memerintabkan: bendaklah mereka menutupkan kain kudung ke dadanya, mereka merobek kain dibabu dan menutupkannya diwajab mereka (Abu Dawud :4104)

Hadis ini menunjukkan bahwa para sahabiyat memahami perintah diatas dengan menutup wajah mereka dengan cara merobek kain dan menutupkannya diwajah sebagai bentuk kepatuhan terhadap perintah Allah Swt.,

Ibnu Hajar dalam kitabnya Fathul Bari" meng informasikan sebuah riwayat dari Ibnu Abi Hatim dari jalan Abdullah bin Utsman bin Khaitsam dari Shafiyyah menerangkan" kami menyebutkan dihadapan Aisyah tentang perempuan-perempuan Quraisy dengan keistimewaan mereka, lalu Aisyah berkata sesungguhnya wanita Quraisy memiliki kelebihan akan tetapi demi Allah aku tidak melihat yang lebih baik ketimbang perempuan Anshar yang sangat membenarkan kitabullah dan beriman pada Alquran saat وليضربن بخمرهن على diturunkan firman Allah جيوبكن maka para laki-laki mereka membacakan yang diturunkan maka tidak seorangpun diantara mereka kecuali berdiri mengambil kain dan mereka shalat mutajirat seolah-olah diatas kepala mereka ada burung gagak. 
Hadis Ketiga.

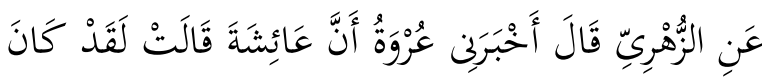

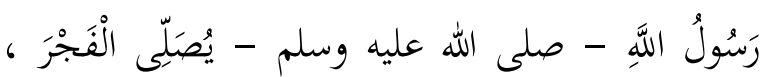

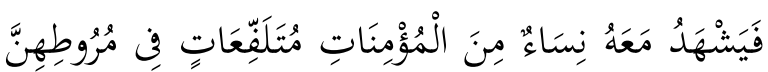

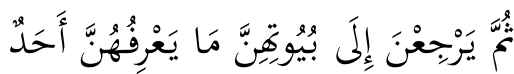

Dari Zubri brkata Unwah mengabariku babwa Aisyah berkata Rasulullah Saw., melaksanakan shalat fajar maka hadir bersamanya kaum perempuan mukminat mutalafat fi muruthibinna (pakaian dari bulu) kemudian mereka kembali kerumah masing-masing tanpa dikenali oleh siapapun. (Bukhari: 372)

\section{Hadis Keempat.}

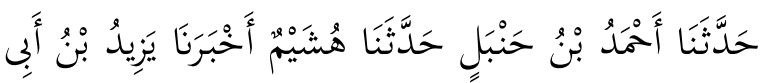

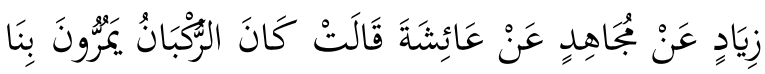

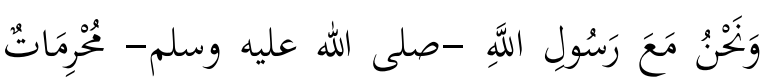

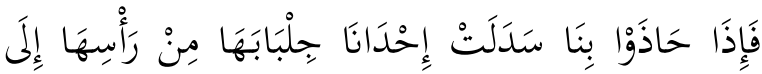

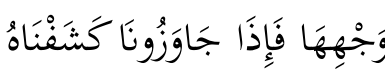

Dari Aisyah ia berkata para penunggang kuda melintasi kami saat kami bersama Rasulullah Saw., sedang melakukan ibram bila mereka mendekati salah seorang dari kami, maka ia (perempuan yang didekati) akan menutupkan kerudungnya dari kepala bingga muka bila mereka berlalu kami membukanya (Abu Dawud, $5: 1835$ )

\section{Hadis Kelima:}

$$
\begin{aligned}
& \text { عن أسماء بنت أبي بكر ، رضي الله عنهما قالت : كنا } \\
& \text { نغطي وجوهنا من الرجال، وكنا نتمشط قبل ذلك في }
\end{aligned}
$$

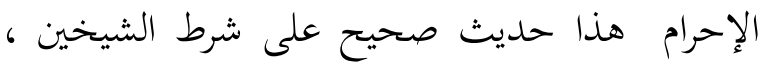

$$
\begin{aligned}
& \text { ولم يخرجاه }
\end{aligned}
$$

Dari Asma binti Abu Bakar ra. Ia berkata "kami menutup muka kami dari penglibatan laki-laki dan kami natamasyyat saat melakukan ibram (Hakim, Mustadrak Hakim: 1621)

Kelima hadis yang penulis angkat diatas menunjukkan aplikasi pelaksanaan menutup aurat dimasa awal turunnya perintah adalah menutup kepala dan wajah mereka sehingga tidak dapat dilihat oleh orang yang bukan muhrim tetapi hadis-hadis tersebut tidak berarti bahwa menutup kepala dan wajah adalah satu-satunya model menutup aurat karena apa yang tersurat dalam teks hadis bukanlah perintah dari rasul untuk menutup kepala dan wajah melainkan respon sahabiyat yang sangat positif dalam melaksanakan perintah menutup aurat dengan tanpa menunggu-nunggu lagi.

Terkait menutup wajah bagi wanita jelas tidak dapat diktegorikan sebagai kewajiban karena rasulullah dalam riwayat yang panjang melarang wanita yang sedang ihram untuk berniqab pada hadis berikut ini:

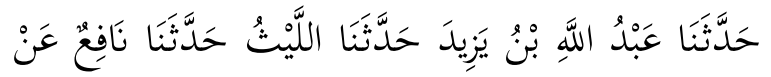

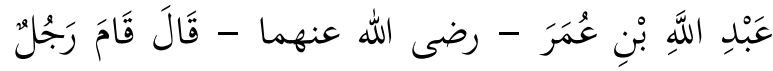

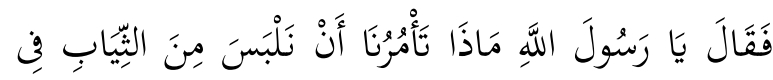

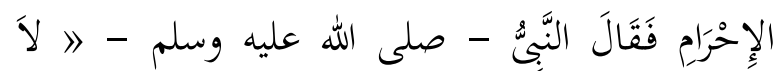

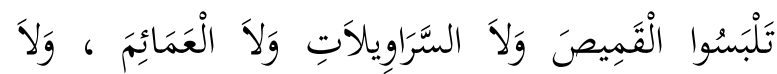

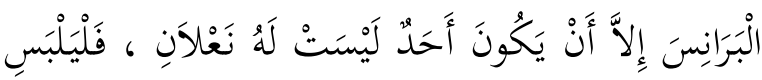

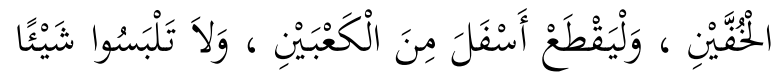

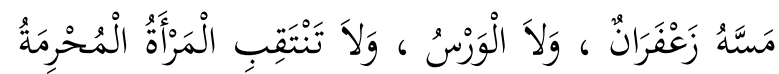

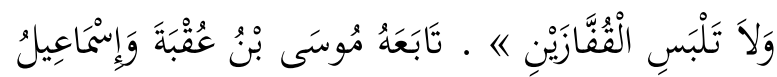

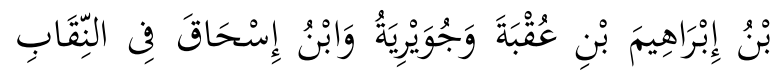

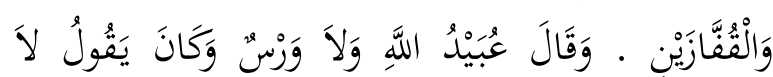

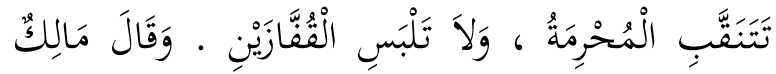

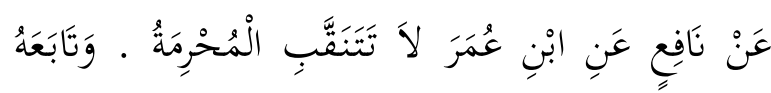

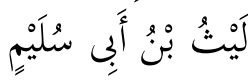

Abdullah bin Yazid bercerita kepada kami bercerita pada kami Al-Laits bercerita pada kami naïf dari Abdullah bin Umar ra ia berkata berdiri seorang laki-lakidan berkata wahai utusan Allah apakah yang engkau perintabkan kepada kami untuk kami pakai saat ibram Rasulullah Saw bersabda "janganlah kalian menggunakan qamish, celana panjang, sorban dikepala baronis, kecuali bagi yang tidak memiliki sandal bendaklah bersepatu bendaklah kalian memotong pakain yang ada 
dibawah kedua mata kaki jangan memakai pakaian yang terkena minyak. Zafaran dan bagi perempuan jangan memakai niqab dan sapu tangan hadis ini memiliki mutabaah dari hadis Musa bin Uqbah dan Ismail bin Ibrabim bin Uqbah dan Juwairiyyah dan ibnu Ishaq terkai Niqab dan qaffar. Abdullah dan Warasy berkata janganlah perempuan yang sedang ibram menggunakan niqab dan jangan menggunakan sapu tangan (Bukhari :1538)

\section{KESMIPULAN}

Dari pemaparan diatas dapat disimpulkan bahwa berhijab dalam arti menutup aurat adalah perintah Allah melalui rasulnya namun batasan berhijab tidaklah disepakati oleh ulama. Di masa awal sahabiyyat menutup wajah dan kepala mereka pelaksanaan berhijab dengan cara menutupi seluruh tubuh termasuk kepala dengan wajah adalah respon kepatuhan sahaiyyat terhadap perintah menggunakan hijab bukan perintah yang sharih dari Rasulullah Saw. seiring waktu muncul trend berhijab dengan tidak terlepas dari pemahaman masing-masing mengenai batasan aurat perempuan sehingga muncul jilbab, niqab, dan khimar yang kesemuanya mengacu pada perintah menutupi aurat dan sangat terpengaruh oleh batasan aurat dalam pemahaman masing-masing mazhab dan fatwa ulama yang dianutnya. Wallabu aalam. 


\section{DAFTAR KEPUSTAKAAN}

Al-Bukhari Abu 'Abdillah, Muhammad bin Isma'il bin Ibrahim al-Mughirah, Shahih Bukhari, Maktabah an-Nahdhah Mekah, 1377 H

Abu Dawud, Sulaiman bin al-Asy-asy bin Syadad bin Amr al-Azdi As-Sijistani, Sunan Abu Dawnd, Wuzarat al Auqaf al Mashriyyah t.th

Ali Abul Hasan Al-Khazin, Lubab at-Takwil fi maani at-tanzil, Maktabah Mauqi at-Tafsir

Al-Asqalani, Ibnu Hajar. Fath al-Bari fi Syarh Shahih al-Bukhari. Mesir: Dar Mashr li al-Thaba'ah. 2001.

Afifi Muhammad Abdul Maqshur Fatowa Almar ah almuslimah Maktabah Daru Ibnu al-Haitsam Cairo 2002

Muslim bin Hajjaj Abul Hasan al-Qusyairi an-Naisaburi, Shabih Muslim, Wuzarat alAuqaf al Mashriyyah, t.th,

Mutawalli, Muhammad Sya'rawi. Tafsir Sya'rawi. tt.

Thantawi, Sayyid, Muhammad, Tafsir Al Wasith li Alquran al-Karim, tt Dar al Ma'rifah li-atThaba'ah

Hakim, Mustadrak ala as-shabihaini, Mauqi Jamiul Hadis,

Ibnu Katsir, Isma’il Abu al-Fida. Tafsir Alquran al-Adhim. Dar al-Fajr li al-Turats. 2002.

Shihab, Muhammad Quraish. Tafsir al-Mishbah: Pesan, Kesan dan Keserasian Alquran, Jakarta: Lentera Hati. 2002.

W.J.S Poerwadaminta, Kamus Umum Bahasa Indonesia Edisi Ketiga Jakarta: Balai Pustaka 2007 